Bull. Chem. Soc. Ethiop. 2021, 35(1), 207-215.

(c) 2021 Chemical Society of Ethiopia and The Authors

ISSN 1011-3924

DOI: https://dx.doi.org/10.4314/bcse.v35i1.18

Printed in Ethiopia

Online ISSN 1726-801X

\title{
NMR CHARACTERIZATION AND FREE RADICAL SCAVENGING ACTIVITY OF PHEOPHYTIN 'A' FROM THE LEAVES OF DISSOTIS ROTUNDIFOLIA
}

\author{
Chisom Friday ${ }^{*}$, OkenwaUchennaIgwe and Ugochukwu Clinton Akwada \\ Department of Chemistry, Michael Okpara University of Agriculture, Umudike, P.M.B. 7267 \\ Umuahia, Abia State, Nigeria
}

(Received September 22, 2020; Revised March 16, 2021; Accepted March 31, 2021)

\begin{abstract}
Dissotis rotundifolia is used traditionally in various parts of Africa for the treatment of various ailments. The air dried and pulverized leaves of Dissotis rotundifolia was extracted with distilled n-hexane and ethylacetate, using Soxhlet apparatus. Isolation and purification were carried out using column and thin layer chromatographic techniques. Fraction B14 gave a single spot on thin layer chromatography with a retention factor (Rf) value of 0.57 . Characterization of B14 was doneusing ${ }^{1} \mathrm{H}-\mathrm{NMR},{ }^{13} \mathrm{C}-\mathrm{DEPT}, \mathrm{COSY}, \mathrm{HSQC}, \mathrm{HMBC}$ and by direct comparison with literature values and pheophytin A was proposed as the structure of the compound. Pheophytin A exhibited a free radical scavenging activity of $10.10 \pm 0.05$ and $19.51 \pm 0.02 \%$ at minimum and maximum concentrations of 1.00 and $4.00 \mathrm{mg} / \mathrm{mL}$, respectively. The acclaimed ethnomedicinal uses of $D$. rotundifolia by the African natives could be linked to the presence of pheophytin A and other phytoconstituents in the plant. This is the first report of the isolation of pheophytin A from D. rotundifolia.
\end{abstract}

KEY WORDS: Dissotis rotundifolia, Pheophytin A, Chromatographic techniques, Free radicals, NMR

\section{INTRODUCTION}

Nigeria is blessed with diverse medicinal plants, of which some have been exploited as food and in the preparation of herbal drugs. D. rotundifolia is one of such plants having found use in ethnomedicine. It is a member of the Melastomaceae family and is native to tropical Africa. $D$. rotundifolia is also known as pink lady in English. The common vernacular names in Nigeria include Nkpisi-nku in Igbo, Ebafo in Benin and Awede in Yoruba [1, 2]. D. rotundifolia is used traditionally in various parts of Africa for the treatment of cough, toothache, migraines, jaundice, fever, arthritis, infertility, eye infections, pneumonia, diarrhea, dysentery, rheumatism, conjunctivitis, gonorrhea, headache, ulcer and trypanosomiasis [1, 3-7]. In Nigeria, it is used mainly for the treatment of rheumatism and painful swellings. The leaf decoction is used to relieve stomachache, diarrhea, cough, conjunctivitis and jaundice $[3,5,8]$. The pharmacological properties of $D$. rotundifolia such as the antidiarrheal, antitrypanosomal, antiplasmodial, antiulcer, antibacterial, antifertility and antioxidant activities have been investigated and reported by other researchers [5-7, 9-11]. Previous researchers isolated four compounds from $D$. rotundifolia namely, vitexin (8- $\beta$-D-glucopyranosyl apigenin), isovitexin (6- $\beta$-D-glucopyranosyl apigenin), orientin (8- $\beta$-D-glycopyranosyl luteolin) and isoorientin (6- $\beta$-D-glycopyranosyl luteolin) [1112].

Certain plant constituents are known to possess free radical scavenging properties and are required in the body to help balance, counteract and to prevent free radical mediated diseases. Such plant constituents include carotenoids, ascorbic acid, tocopherol, phenolics, flavonoids and certain mineral elements like zinc, manganese and selenium [13, 14]. There is also need to establish the free radical scavenging activity of other compounds. Free radicals, at low or moderate concentrations, have been reported to play various beneficial roles in the body such as cellular structure synthesis, defense against pathogenic organisms, elimination of tumor cells, cellular signaling pathways and the induction of mitogenic response [15-18]. However, the

*Corresponding author. E-mail: emmafric20@gmail.com ; friday.chisom@mouau.edu.ng This work is licensed under the Creative Commons Attribution 4.0 International License 
imbalance in the production of free radicals in the body and the defense mechanisms of natural free radical scavengers cause oxidative damage to biomolecules such as lipids, proteins and deoxyribonucleic acid (DNA). Oxidation of these biomolecules has been implicated in various diseases such as cardiovascular diseases, cancer, stroke, chronic inflammation, neurodegenerative disorders, diabetes, atherosclerosis, eye disorders and aging [19-21].

In this study, we report the isolation, characterization and assessment of the free radical scavenging activity of pheophytin A from the leaves of $D$. rotundifolia. This is the first report of the isolation of pheophytin A from D. rotundifolia.

\section{EXPERIMENTAL}

Sample collection and preparation. D. rotundifolia leaves were collected from NdiolumbeNvosi, Isiala-Ngwa South L.G.A., Abia State, Nigeria, between June and September, 2018. The plant material was identified and authenticated by Mr. I. K. Ndukwe, a specialist in the Plant Taxonomy Section, Forestry Department, Michael Okpara University of Agriculture, Umudike, Abia State, Nigeria. The leaves of D. rotundifolia were washed thoroughly with distilled water. The leaves were air-dried under shades. Thereafter, the dried plant leaves were powdered using electric blender.

Sample extraction and compound isolation. Extraction of plant material was carried out by Soxhlet extraction method using n-hexane and ethylacetate as solvents respectively. The extracts were concentrated using a rotary evaporator at room temperature and left on the laboratory bench for 2 days. The n-hexane and ethylacetate extracts were pooled together. The column was packed with silica gel of 60-120 mesh size and the extract eluted with different fractions of nhexane and ethylacetate. Solvent mixture of n-hexane and ethylacetate $(90: 10 \mathrm{~mL})$ was introduced and collection of fractions in well labeled vials began just before the plant material travelled to the column neck. This continued for the following solvent mixtures - 80:20, 70:30, $60: 40,50: 50,40: 60,30: 70,20: 80,10: 90,0: 100$. Thereafter, a more polar solvent, methanol (200 $\mathrm{mL}$ ) was used to elute the more polar components from the column. A total of 53 vials were collected. Each fraction was spotted using a capillary tube on a precoated TLC plate and developed in a solvent mixture of $3 \mathrm{~mL}: 7 \mathrm{~mL}$ (ethylacetate : hexane). Fraction B14 (a greenishyellow solid) gave a single spot on TLC with $\mathrm{R}_{\mathrm{f}}$ value of 0.57 , using $3 \mathrm{~mL}$ ethylacetate: $7 \mathrm{~mL} \mathrm{n}$ hexane. The fraction B14 was packaged in a vial and sent to University of Strathclyde, Glasgow, Scotland for spectral analysis.

Structure elucidation. Structure elucidation were carried out using $1 \mathrm{D}{ }^{1} \mathrm{H}(500 \mathrm{MHz})$, homonuclear 2D ${ }^{13} \mathrm{C}$ (DEPT 135); ${ }^{1} \mathrm{H}-{ }^{1} \mathrm{H}$ COSY (correlatiion spectroscopy) and heteronuclear 2D ${ }^{1} \mathrm{H}-{ }^{13} \mathrm{C}$ HSQC (heterounuclear single quantum coherence) and HMBC (heteronuclear multiple bond correlation) NMR using Bruker instruments.

Free radical scavenging activity determination. The free radical scavenging activity of the samples were determined using the 1,1-diphenyl-2-picrylhydrazyl ( $\alpha, \alpha$-diphenyl- $\beta$-picrylhydrazyl; DPPH) method as described by Manzocco et al. [22]. $1.0 \mathrm{~g}$ of DPPH, a stable radical was dissolved in $100 \mathrm{~mL}$ of methanol. $3.0 \mathrm{~mL}$ of different concentrations of the test samples were added to $3.0 \mathrm{~mL}$ of a $0.004 \%$ methanol solution of DPPH and incubated for $30 \mathrm{~min}$ at room temperature. The decrease in absorbance of the solution brought about by the test samples was measured at $517 \mathrm{~nm}$ using a spectrophotometer. Ascorbic acid was used as a reference standard. The radical scavenging activity was calculated as the percentage inhibition of DPPH discoloration using the equation below:

$$
\% \text { inhibition of DPPH radical }=\frac{\text { Ablank }- \text { Asample }}{\text { Ablank }} \times 100
$$

Bull. Chem. Soc. Ethiop. 2021, 35(1) 
where; Ablank is the absorbance of the control reaction solution (containing all reagents except the test sample); Asample is the absorbance of the test sample.

\section{RESULTS AND DISCUSSION}

The ${ }^{1} \mathrm{H}$ NMR and ${ }^{13} \mathrm{C}$-DEPT (135) chemical shift for fraction B14, a greenish-yellow solid with $\mathrm{R}_{\mathrm{f}}$ value of 0.57 is shown in Table 1 . The ${ }^{1} \mathrm{H}-\mathrm{NMR}$ for fraction $\mathrm{B} 14$ showed the presence of ten (10) methyl, thirteen (13) methylene, eleven (11) methine and two (2) ester protons.

Table 1. ${ }^{1} \mathrm{H}(500 \mathrm{MHz})$ and ${ }^{13} \mathrm{C}-\mathrm{DEPT}$ (135) NMR chemical shift for fraction B14.

\begin{tabular}{|c|c|c|c|}
\hline Position & $\begin{array}{l}{ }^{1} \mathrm{H} \text { Chemical shift } \\
\text { (ppm) }\end{array}$ & ${ }^{13} \mathrm{C}$-DEPT chemical shift (ppm) & Assignment \\
\hline 1 & - & - & - \\
\hline 2 & - & - & - \\
\hline $2^{1}$ & 3.42 & 12.10 & $-\mathrm{CH}_{3}$ \\
\hline 3 & - & - & - \\
\hline $3^{1}$ & 8.00 & 129.02 & $=\mathrm{CH}$ \\
\hline $3^{2}$ & 6.31 & 122.79 & $=\mathrm{CH}_{2}$ \\
\hline 4 & - & - & - \\
\hline 5 & 9.38 & 97.91 & $=\mathrm{CH}$ \\
\hline 6 & - & - & - \\
\hline 7 & - & - & - \\
\hline $7^{1}$ & 3.24 & 11.30 & $-\mathrm{CH}_{3}$ \\
\hline 8 & - & - & - \\
\hline $8^{1}$ & 3.68 & 19.50 & $-\mathrm{CH}_{2}$ \\
\hline $8^{2}$ & 1.71 & 17.50 & $-\mathrm{CH}_{3}$ \\
\hline 9 & - & - & - \\
\hline 10 & 9.52 & 104.21 & $=\mathrm{CH}$ \\
\hline 11 & - & - & - \\
\hline 12 & - & - & - \\
\hline $12^{1}$ & 3.72 & 12.28 & $-\mathrm{CH}_{3}$ \\
\hline 13 & - & - & - \\
\hline $13^{1}$ & - & - & - \\
\hline $13^{2}$ & 6.31 & 121.62 & $-\mathrm{CH}$ \\
\hline $13^{3}$ & - & - & - \\
\hline $13^{4}$ & 3.92 & 53.38 & $-\mathrm{COOCH}_{3}$ \\
\hline 14 & - & - & - \\
\hline 15 & - & - & - \\
\hline 16 & - & - & - \\
\hline 17 & 4.24 & 51.90 & $-\mathrm{CH}$ \\
\hline $17^{1}$ & $2.36 / 2.66$ & 29.69 & $-\mathrm{CH}_{2}$ \\
\hline $17^{2}$ & $2.22 / 2.58$ & 31.19 & $-\mathrm{CH}_{2}$ \\
\hline $17^{3}$ & - & - & - \\
\hline 18 & 4.50 & 50.37 & $-\mathrm{CH}$ \\
\hline $18^{1}$ & 1.84 & 22.70 & $-\mathrm{CH}_{3}$ \\
\hline 19 & - & - & - \\
\hline 20 & 8.58 & 93.63 & $=\mathrm{CH}$ \\
\hline $\mathrm{P}_{1}$ & 4.50 & 61.58 & -COOCH2 \\
\hline $\mathrm{P}_{2}$ & 5.16 & 117.78 & $=\mathrm{CH}$ \\
\hline $\mathrm{P}_{3}$ & - & - & - \\
\hline $\mathrm{P}_{3}^{1}$ & 1.56 & 29.08 & $-\mathrm{CH}_{3}$ \\
\hline $\mathrm{P}_{4}$ & 1.85 & 39.85 & $=\mathrm{C}-\mathrm{CH}_{2}$ \\
\hline
\end{tabular}

Bull. Chem. Soc. Ethiop. 2021, 35(1) 


\begin{tabular}{|c|c|c|c|}
\hline $\mathrm{P}_{5}$ & 1.61 & 25.03 & $-\mathrm{CH}_{2}$ \\
\hline $\mathrm{P}_{6}$ & 1.02 & 36.67 & $-\mathrm{CH}_{2}$ \\
\hline $\mathrm{P}_{7}$ & 1.32 & 32.77 & $-\mathrm{CH}$ \\
\hline $\mathrm{P}_{7} \mathrm{I}_{8}$ & 0.80 & 29.08 & $-\mathrm{CH}_{3}$ \\
\hline $\mathrm{P}_{9}$ & 1.21 & 37.28 & $-\mathrm{CH}_{2}$ \\
\hline $\mathrm{P}_{10}$ & 1.13 & 24.71 & $-\mathrm{CH}_{2}$ \\
\hline $\mathrm{P}_{11}$ & 1.23 & 37.28 & $-\mathrm{CH}_{2}$ \\
\hline $\mathrm{P}_{11}^{1}$ & 1.32 & 31.67 & $-\mathrm{CH}$ \\
\hline $\mathrm{P}_{12}$ & 0.81 & 29.35 & $-\mathrm{CH}_{3}$ \\
\hline $\mathrm{P}_{13}$ & 1.23 & 37.28 & $-\mathrm{CH}_{2}$ \\
\hline $\mathrm{P}_{14}$ & 1.27 & 25.03 & $-\mathrm{CH}_{2}$ \\
\hline $\mathrm{P}_{15}$ & 1.13 & 39.37 & $-\mathrm{CH}_{2}$ \\
\hline $\mathrm{P}_{15}^{1}$ & 1.52 & 31.94 & $-\mathrm{CH}$ \\
\hline $\mathrm{P}_{16}$ & 0.86 & 29.45 & $-\mathrm{CH}_{3}$ \\
\hline & 0.86 & 22.70 & $-\mathrm{CH}_{3}$ \\
\hline
\end{tabular}

The singlet signals at $9.52 \mathrm{ppm}, 9.38 \mathrm{ppm}$, and $8.58 \mathrm{ppm}$ are characteristic of $\mathrm{H}-10, \mathrm{H}-5$ and $\mathrm{H}-20$ protons respectively, indicating porphyrin unit of olefinic methinic $(=\mathrm{CH})$ protons bridging the pyrrole rings. The signals at $3.72 \mathrm{ppm}\left(\mathrm{s}, \mathrm{Me}-12^{1}\right), 3.24 \mathrm{ppm}\left(\mathrm{s}, \mathrm{Me}-7^{1}\right), 3.42 \mathrm{ppm}$ $\left(\mathrm{Me}-2^{1}\right) ; 1.84 \mathrm{ppm}\left(\mathrm{d}, \mathrm{J}=7.3 \mathrm{~Hz}, \mathrm{Me}-18^{1}\right)$ and $1.71 \mathrm{ppm}\left(\mathrm{J}=7.6 \mathrm{~Hz}, \mathrm{Me}-8^{2}\right)$ corresponds to substituents (comprising of four methyl and one ethyl groups) attached to the pyrrole rings of the porphyrin unit (Table 1). Other signals include; a triplet at $3.68 \mathrm{ppm}\left(2 \mathrm{H}-8^{1}\right)$, methoxy group at $3.92 \mathrm{ppm}\left(\mathrm{s}, 3 \mathrm{H}-13^{4}\right)$ as well as signals at $8.00 \mathrm{ppm}\left(\mathrm{dd}, 1 \mathrm{H}-3^{1}, \mathrm{~J}=17.8 \mathrm{~Hz}\right.$ and $\left.11.5 \mathrm{~Hz}\right)$ and $6.31 \mathrm{ppm}\left(\mathrm{d}, 1 \mathrm{H}-3^{2}, \mathrm{~J}=17.8 \mathrm{~Hz}\right)$ characteristic of olefinic protons. Furthermore, the signals at $4.24 \mathrm{ppm}\left(\mathrm{m}, 2 \mathrm{H}-\mathrm{P}_{1}\right)$ and $5.16 \mathrm{ppm}\left(\mathrm{m}, 1 \mathrm{H}-\mathrm{P}_{2}\right)$ are of ester and olefinic protons of the phytyl group, confirming the esterification as well as the presence of phytol group in the structure.

The ${ }^{1} \mathrm{H}-{ }^{1} \mathrm{H}$ - COSY (Figure 1) showed singlet signals at $9.52 \mathrm{ppm}, 9.38 \mathrm{ppm}$ and $8.58 \mathrm{ppm}$, characteristic of H-10, H-5 and H-20 protons, respectively. Signals were also observed at 3.68 $\operatorname{ppm}\left(\mathrm{s}, \mathrm{Me}-12^{1}\right), 3.42 \mathrm{ppm}\left(\mathrm{Me}-2^{1}\right), 3.24 \mathrm{ppm}\left(\mathrm{s}, \mathrm{Me}-7^{1}\right), 1.84 \mathrm{ppm}\left(\mathrm{d}, \mathrm{J}=7.3 \mathrm{~Hz}, \mathrm{Me}-18^{1}\right)$ and $1.71 \mathrm{ppm}\left(\mathrm{t}, \mathrm{J}=7.6 \mathrm{~Hz}, \mathrm{Me}-8^{2}\right)$ attributed to four methyl and one ethyl groups bonded to the pyrrole ring of the porphyrin unit. The ${ }^{1} \mathrm{H}-{ }^{1} \mathrm{H}$ correlation signals at $4.24 \mathrm{ppm}\left(\mathrm{m}, 2 \mathrm{H}-\mathrm{P}_{1}\right)$ and $5.16 \mathrm{ppm}\left(\mathrm{m}, 1 \mathrm{H}-\mathrm{P}_{2}\right)$ were assigned to the ester and olefinic protons of the phytyl group, and correlated in the HSQC/DEPT with carbon signals at $61.58 \mathrm{ppm}\left(\mathrm{CH}_{2}-\mathrm{P}_{1}\right)$ and $117.78 \mathrm{ppm}$ $\left(=\mathrm{CH}-\mathrm{P}_{2}\right)$. Thus, confirming the esterification of the porphyrin moeity at $\mathrm{C}-17^{3}$ by phytol.

In the ${ }^{13} \mathrm{C}$-DEPT spectrum (Table 1), the observed signals at $104.21 \mathrm{ppm}, 97.91 \mathrm{ppm}$ and $93.63 \mathrm{ppm}$ correspond to the olefinic methinic $(=\mathrm{CH})$ carbons of $\mathrm{C}-10, \mathrm{C}-5$ and $\mathrm{C}-20$, indicating a porphyrin moiety. The signals at $51.90 \mathrm{ppm}$ and $50.37 \mathrm{ppm}$ correspond to $\mathrm{C}-17$ and $\mathrm{C}-18$ methine carbons of the porphyrin moiety, while the signals at $61.58 \mathrm{ppm}\left(-\mathrm{COOCH}_{2}, \mathrm{P}_{1}\right)$ corresponds to the oxymethylene carbon which confirmed the esterification of the porphyrin ring by phytol group.

The HSQC spectra (Figure 2) showed correlations between the carbon atom $(\mathrm{C}-10)$ at $104.21 \mathrm{ppm}$ and the proton (H-10) at $9.52 \mathrm{ppm}$; C-5 at $97.91 \mathrm{ppm}$ and $\mathrm{H}-5$ at $8.55 \mathrm{ppm}$ and the carbon atom $(\mathrm{C}-20)$ at $93.63 \mathrm{ppm}$ and the proton $(\mathrm{H}-20)$ at $8.58 \mathrm{ppm}$, characteristic of porphyrin moiety of olefinic methine $(=\mathrm{CH})$ groups bonded to pyrrole rings. Also, single bond coupling were observed between the carbon atom $\left(\mathrm{C}-12^{1}\right)$ at $12.20 \mathrm{ppm}$ and the protons $\left(\mathrm{H}-12^{1}\right)$ at 3.72 ppm; $\mathrm{C}-2^{1}$ at $12.10 \mathrm{ppm}$ and $\mathrm{H}-2^{1}$ at 3.42 ppm; $\mathrm{C}-7^{1}$ at $11.30 \mathrm{ppm}$ and $\mathrm{H}-7^{1}$ at $3.24 \mathrm{ppm}$; $\mathrm{C}-18^{1}$ at $22.70 \mathrm{ppm}$ and $\mathrm{H}-18^{1}$ at $1.84 \mathrm{ppm} ; \mathrm{C}-8^{2}$ at $17.50 \mathrm{ppm}$ and $\mathrm{H}-8^{2}$ at $1.71 \mathrm{ppm}$, are characteristic of four methyl and one ethyl substituents attached to the pyrrole rings of the porphyrin unit. In addition, there were also correlations between the carbon atom $\left(\mathrm{C}-8^{1}\right)$ at $19.50 \mathrm{ppm}$ and the protons $\left(\mathrm{H}-8^{1}\right)$ at $3.68 \mathrm{ppm}$; the oxymethyl $\left(\mathrm{COOCH}_{3}\right)$ carbon $\left(\mathrm{C}-13^{4}\right)$ at $53.38 \mathrm{ppm}$ and its protons $\left(\mathrm{H}-13^{4}\right)$ at $3.92 \mathrm{ppm}$; the olefinic carbons $\left(\mathrm{C}-3^{1}\right)$ at $129.02 \mathrm{ppm}$ and $\mathrm{C}-3^{2}$ at $122.79 \mathrm{ppm}$ and their corresponding protons $\left(\mathrm{H}-3^{1}\right)$ at $8.00 \mathrm{ppm}$ and $\left(\mathrm{H}-3^{2}\right)$ at $6.31 \mathrm{ppm}$, respectively. All 
these values indicate the porphyrin moeity of pheophytin A. Furthermore, there was coupling between the oxymethylene carbon $\left(\mathrm{C}-\mathrm{P}_{1}\right)$ at $61.58 \mathrm{ppm}$ and it's oxymethylene protons $\left(2 \mathrm{H}-\mathrm{P}_{1}\right)$ at $4.50 \mathrm{ppm}$; the olefinic carbon $\left(\mathrm{C}-\mathrm{P}_{2}\right)$ at $117.78 \mathrm{ppm}$ and its corresponding proton $\left(1 \mathrm{H}-\mathrm{P}_{2}\right)$ at 5.16 $\mathrm{ppm}$. These are characteristic of the phytol group of pheophytin A.

In the HMBC spectrum (Figure 3), the triplet at $8.00 \mathrm{ppm}\left(\mathrm{H}-3^{1}\right)$ displayed correlation to the olefinic (methylene) carbon at $122.79 \mathrm{ppm}\left(\mathrm{C}-3^{2}\right)$ via ${ }^{2} \mathrm{~J}$ coupling, while the doublet at $6.31 \mathrm{ppm}$ $\left(\mathrm{H}-3^{2)}\right.$ showed ${ }^{2} \mathrm{~J}$ coupling to the olefinic (methine) carbon at $129.02 \mathrm{ppm}\left(\mathrm{C}-3^{1}\right)$, establishing the attachment of $-\mathrm{CH}=\mathrm{CH}_{2}$ group to $\mathrm{C}-3$. The methyl $\left(\mathrm{Me}-8^{2}\right)$ at $1.71 \mathrm{ppm}$ showed a ${ }^{2} \mathrm{~J}$ coupling to the methylene at $19.50 \mathrm{ppm}\left(\mathrm{C}-8^{1}\right)$, confirming the attachment of $-\mathrm{CH}_{2} \mathrm{CH}_{3}$ (ethyl) group at $\mathrm{C}-8$. The two methine protons at $4.24 \mathrm{ppm}(\mathrm{H}-17)$ and $4.50 \mathrm{ppm}(\mathrm{H}-18)$ also correlated to $\mathrm{C}-17^{1}$ via ${ }^{2} \mathrm{~J}$ and ${ }^{3} \mathrm{~J}$ coupling, respectively. ${ }^{3} \mathrm{~J}$ coupling was also observed between $\mathrm{H}-17$ and $\mathrm{C}-17^{2}$. The methyl protons at $1.84 \mathrm{ppm}\left(\mathrm{H}-18^{1}\right)$ correlated to $\mathrm{C}-17$ at $51.90 \mathrm{ppm}$ and $\mathrm{C}-18$ at $50.37 \mathrm{ppm}$ via ${ }^{3} \mathrm{~J}$ and ${ }^{2} \mathrm{~J}$ coupling, respectively, whereas the methine (olefinic) proton at $8.58 \mathrm{ppm}(\mathrm{H}-20)$ displayed ${ }^{3} \mathrm{~J}$ coupling with the methine carbon (C-18). Furthermore, the oxymethylene protons at $4.50 \mathrm{ppm}\left(\mathrm{H}-\mathrm{P}_{1}\right)$ correlated to the methine (olefinic) carbon at $117.78 \mathrm{ppm}\left(\mathrm{C}-\mathrm{P}_{2}\right)$, establishing the presence of phytol group in the structure.

A comparative analysis of the DEPT NMR spectrum with ${ }^{13} \mathrm{C}$-NMR spectrum reported in literature showed that there were nineteen carbon atoms with no attached protons. The signals for these carbons were lacking in the DEPT NMR spectrum. With the exception of these signals, all other data obtained from ${ }^{1} \mathrm{H},{ }^{1} \mathrm{H}-{ }^{1} \mathrm{H}-\mathrm{COSY}$, DEPT, HSQC and HMBC were in agreement with that reported in literature for pheophytin A [23-26]. Thus confirming fraction B14, isolated from Dissotis rotundifolia as pheophytin A. Although this compound (pheophytin A) is known, it is being reported from Dissotis rotundifolia leaves for the first time.

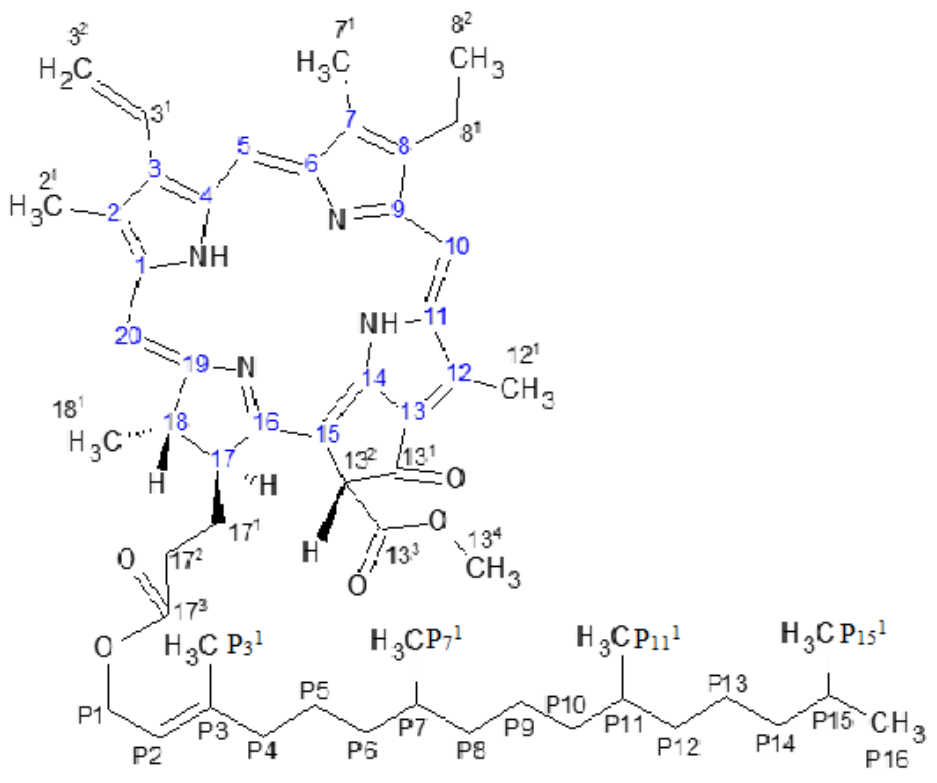

Pheophytin A 


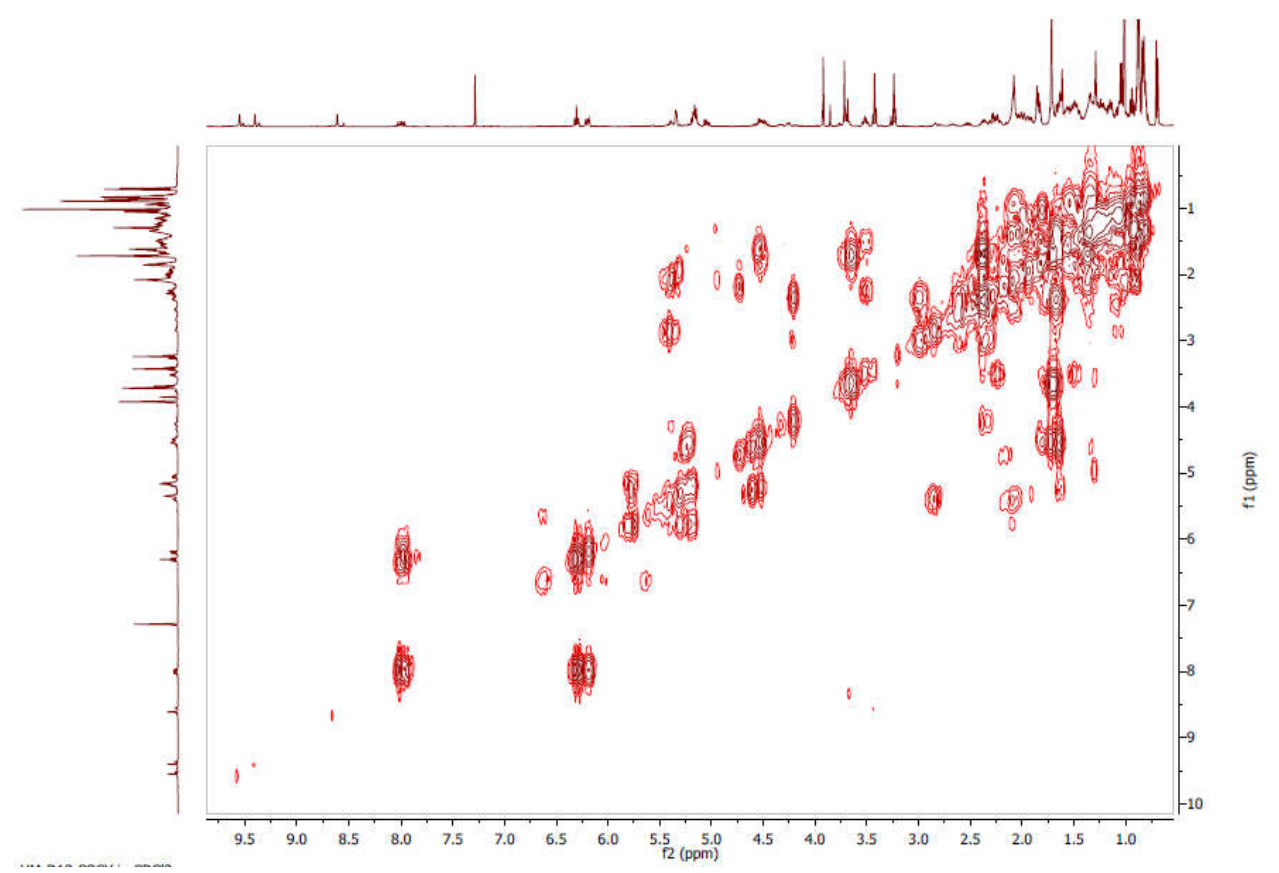

Figure 1. COSY NMR spectrum for fraction B14.

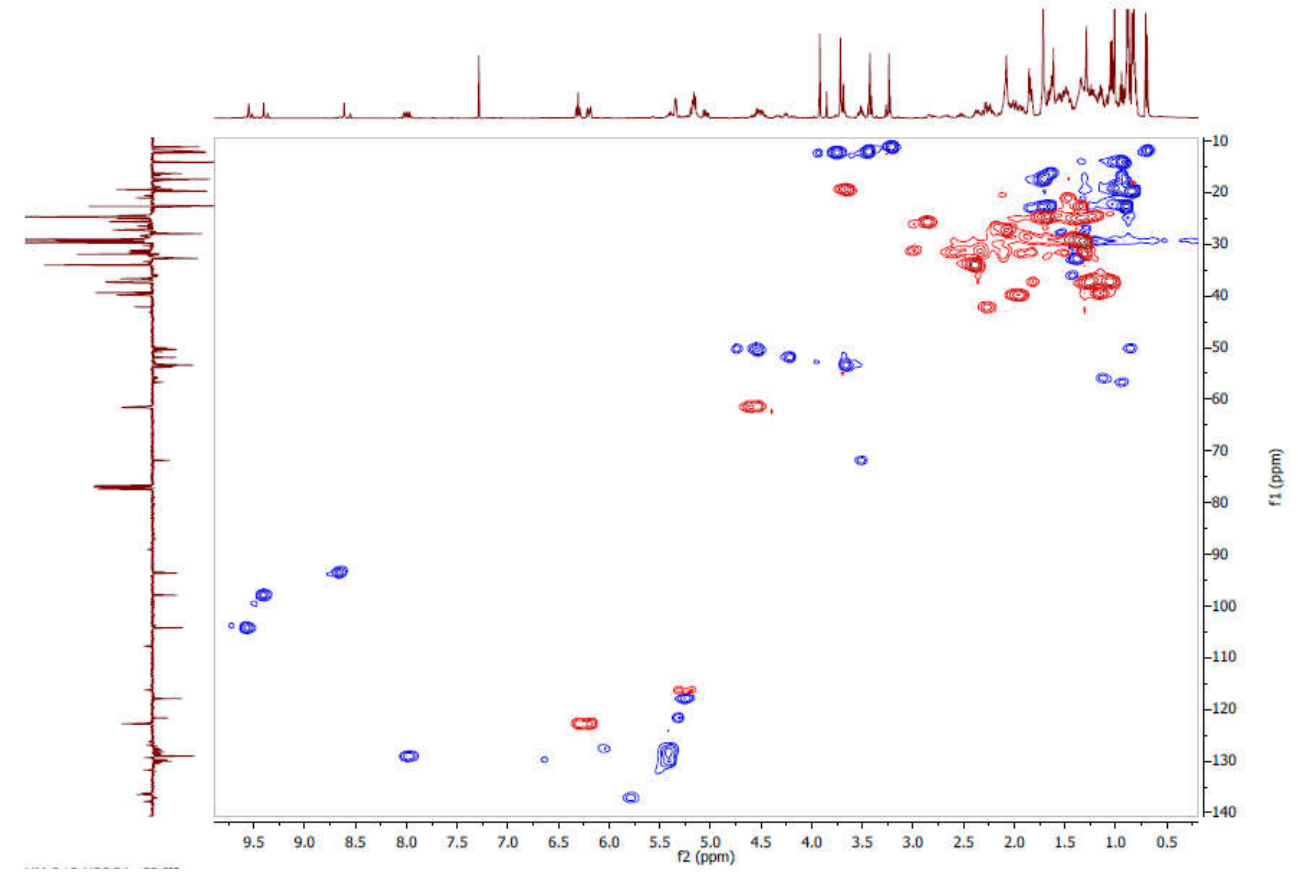

Figure 2. HSQC NMR spectrum for fraction B14.

Bull. Chem. Soc. Ethiop. 2021, 35(1) 


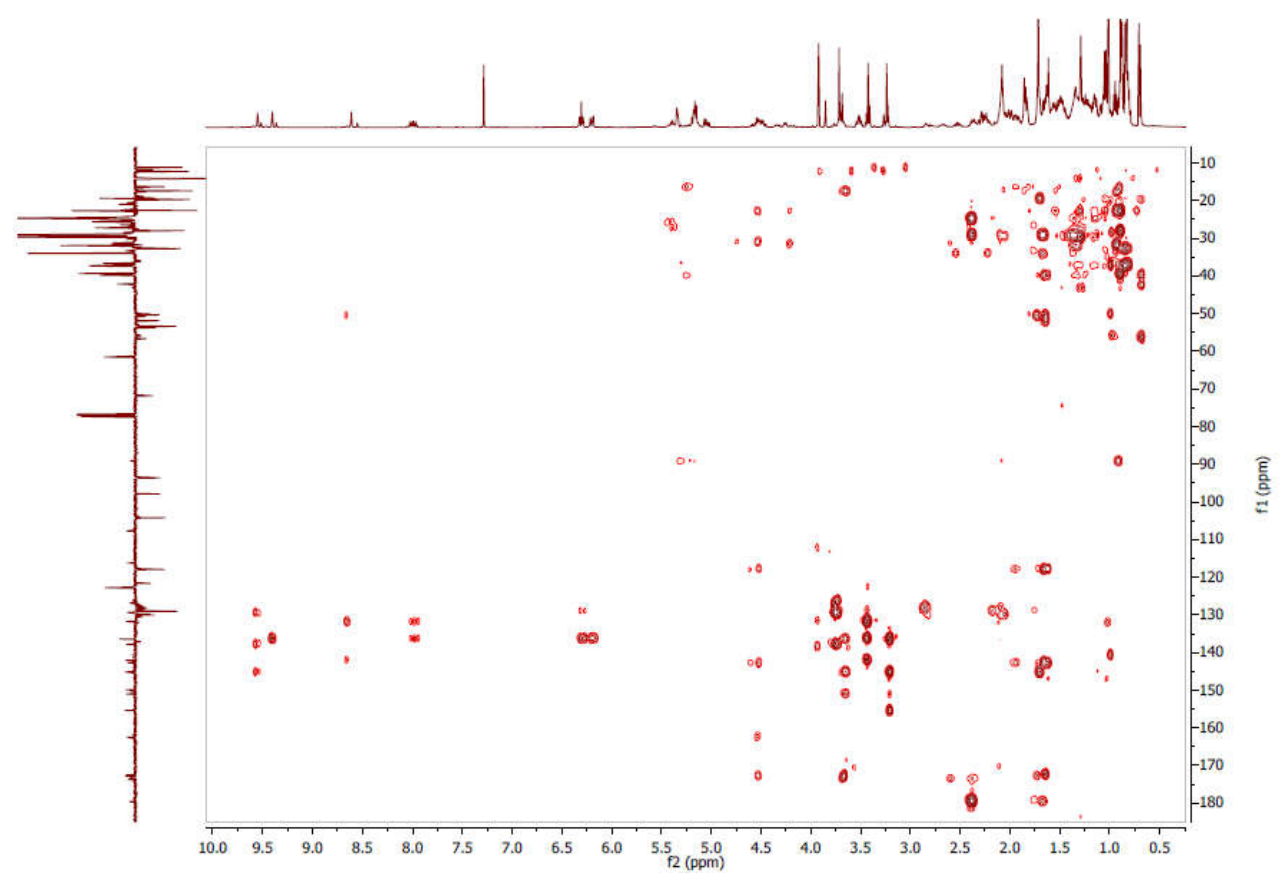

Figure 3. HMBC NMR spectrum for fraction B14.

Free radical scavenging activity. The free radical scavenging activity of pheophytin A (B14) isolated from the leaves of $D$. Rotundifolia against DPPH is shown in Table 2.

Table 2. Free radical scavenging activity of pheophytin A (B14).

\begin{tabular}{|c|c|c|}
\hline Concentration $(\mathrm{mg} / \mathrm{mL})$ & Pheophytin A (\%) & Ascorbic acid (\%) \\
\hline 1.00 & $10.10 \pm 0.05$ & $43.02 \pm 0.52$ \\
\hline 2.00 & $13.30 \pm 0.01$ & $50.21 \pm 0.03$ \\
\hline 3.00 & $16.02 \pm 0.02$ & $62.22 \pm 0.02$ \\
\hline 4.00 & $19.51 \pm 0.02$ & $70.35 \pm 0.41$ \\
\hline
\end{tabular}

Values are means \pm standard deviation of triplicate determinations.

At $1.00 \mathrm{mg} / \mathrm{mL}$ concentration, pheophytin A showed free radical scavenging activity of $10.10 \pm 0.05 \%$, while that of ascorbic acid used as reference standard was $43.02 \pm 0.52 \%$. At the highest concentration of $4.00 \mathrm{mg} / \mathrm{mL}$, the free radical scavenging activity of pheophytin A was $19.51 \pm 0.02 \%$, while that of ascorbic acid was $70.35 \pm 0.41 \%$. Free radicals cause oxidative stress to biological molecules and are implicated in various diseases such as cardiovascular diseases, cancer, stroke, chronic inflammation, neurodegenerative disorders, diabetes, aging and lung disorders such as asthma, chronic obstructive pulmonary disease and tuberculosis [19-21, 27]. The ability of pheophytin A to exhibit free radical scavenging activity, indicates that it possesses free radical scavenging property and could play an important role in the prevention of free radical mediated diseases. The antioxidant mechanism of pheophytin A include chelation of $\mathrm{Fe}(\mathrm{II})$ and $\mathrm{Cu}(\mathrm{II})$ to prevent lipid peroxidation which causes damage to DNA and by electron transfer through the conjugated double bonds in the porphyrin ring, thereby stabilizing the radical compound [28]. 


\section{CONCLUSION}

This is the first report on the isolation of pheophytin A from the leaves of $D$. rotundifolia. The isolated compound (pheophytin A) showed free radical scavenging activity and may play a contributory role in the prevention and treatment of ailments caused by free radicals.

\section{ACKNOWLEDGEMENTS}

We are grateful to Reliable Research Laboratory, Umuahia, for making use of their laboratory to carryout antioxidant study. We are also grateful to Prof. John Igoli for spectral analysis at the University of Strathclyde, Glasgow, Scotland and also to Mr. I. K. Ndukwe of Forestry Department, Michael Okpara University of Agriculture, Umudike, for identifying and authenticating our plant sample.

\section{REFERENCES}

1. Abere, T.A.; Onwukaeme, D.N.; Ebuka, C.J. Pharmacognostic evaluation of the leaves of Dissotis rotundifolia Triana (Melastomataceae). Afr. J. Biotechnol. 2009, 8, 113-115.

2. Makanjuola, V.O.; Tams, G.E.; Ippiniwa, D.A. The effect of methanolic extract of Dissotis rotundifolia on cadmium induced testicular damage in Wistar rats. IOSR J. Pharm. 2014, 4, 56-65.

3. Gill, L.S. Ethnomedical Uses of Plants in Nigeria, UNIBEN Press: Benin City; 1992; p 103.

4. Noumi, E.; Yomi, A. Medicinal plants used in intestinal diseases in Mbalmayo Region. Fitoterapia 2001, pp 246-254.

5. Mann, A.; Gbate, M.; Umar, A. Medicinal and Economic Plants of Nupe Land. Jube - Evans Books and Publications: Bida, Niger State, Nigeria; 2003; $\mathrm{p} 276$.

6. Olufemi, M.V.; Tams, G.E.; Adebayo, I.A. Effects of ethanol extract of Dissotis rotundifolia on the histology of the ovary, uterus and gonadotropins of adult female wistar rats. Ann. Biol. Sci. 2014, 2, 8-22.

7. Nondo, R.S.O.; Moshi, M.J.; Erasto, P.; Zofou, D.; Njouendou, A.J.; Wanji, S.; Ngemenya, M.N.; Titanji, V.P.K.A.W. and Masimba, P.J. Ethnobotanical survey and in vitro antiplasmodial activity of medicinal plants used to treat malaria in Kagera and Lindi regions, Tanzania. J. Med. Plant Res. 2015, 9, 179-192.

8. Abere, T.A.; Okoto, P.E.; Agoreyo, F.O. Antidiarrhoea and toxicological evaluation of the leaf extract of Dissotis rotundifolia Triana (Melastomataceae). BMC Complement. Altern. Med. 2010, 10, 71 .

9. Kokwaso, J.C. Medicinal Plants of East Africa, General Printers: Nairobi; 1976; p 198.

10. Adinortey, M.B. Pharmacological and toxicological evaluation in rats of Dissotis rotundifolia: A medicinal plant traditionally used in Ghana for the management of peptic ulcer, PhD Dissertation, Kwama Nkrumah University of Science and Technology, Kumasi, Ghana, 2015.

11. Soyinka, J.O.; Oguntade, T.O.; Omawunmi, G.O.; Idowu, T.O.; Ogundaini, A.O. Antioxidant and antimicrobial constituents of Dissotiserecta and Dissotis rotundifolia. Niger. J. Pharm. Res. 2008, 7, 76-82.

12. Rath, G.; Toure, A.; Nianga, M.; Wolfender, J.L.; Hostettmann, K. Characterization of Cglycosylflavones from Dissotis rotundifolia by liquid chromatography- UV diode array detection- tandem mass spectrometry. Chromatographia 1995, 41, 332-346.

13. Pham-Huy L.A.H.; Pham-Huy, C. Free radicals, antioxidants in disease and health. Int. J. Biomed. Sci. 2008, 4, 89-96.

14. Kabel, A.M. Free radicals and antioxidants: Role of enzymes and nutrition. World J. Nutr. Health 2014, 2, 35-38. 
15. Droge, W. Free radicals in the physiological control of cell function. Physiol. Rev. 2002, 82, 47-95.

16. Pacher, P.; Beckman, J.S.; Liaudet, L. Nitric oxide and peroxynitrite in health and disease. Physiol. Rev. 2007, 87, 315-424.

17. Genestra, M. Oxyl radicals, redox-sensitive signalling cascades and antioxidants. Cell Signal. 2007, 19, 1807-1819.

18. Young, I.; Woodside, J. Antioxidants in health and disease. J. Clin. Pathol. 2001, 54, 176186.

19. Pisoschi, A.M.; Cheregi, M.C.; Danet, A.F. Total antioxidant capacity of some commercial fruit juices: Electrochemical and spectrophotometrical approches. Molecules 2009, 14, 480893.

20. Hou, D.X.; Kumamoto, T. Flavonoids as protein kinase inhibitors for cancer chemoprevention: Direct binding and molecular modeling. Antioxid. Redox Signal. 2010, 13, 691-719.

21. Dwaliwal, J.S.; Singh, H. Free radicals and antioxidants in health and disease. Int. J. Oral Health Med. Res. 2015, 2, 97-99.

22. Manzocco, L.; Anese, M.; Nicoli, M.C. Antioxidant properties of tea extracts as affected by processing. Lebens-mittel-Wissen-schaft Und. Technologie 1998, 31, 694-698.

23. Chaves, O.S.; Gomes, R.A.; Tomaz, A.C.; Fernandes, M.G.; Graças Mendes, L.J.R.; Agra, M.F., Braga, V.A., Souza, M.F.V. Secondary metabolites from Sida rhombifolia L. (Malvaceae) and the vasorelaxant activity of cryptolepinone. Molecules 2013, 18, 27692777.

24. Rodrigues, G.C.R.; Bastos, I.V.G.A.; Pereira-Junior, J.A.S.; Filho, R.C.S.P.; Almeida, M.C.S.; Braz-Filho, R.; Da-Silva, T.G.; Lemos, T.L.G.; De-Melo, S.J.M. Free radical scavenging activity and cytotoxicity from leaves of Guettarda platypoda. Issues Biol. Sci. Pharm. Res. 2014, 2, 90-105.

25. Gomes, R.A.; Teles, Y.C.F.; Pereira, F.O.; Rodrigues, L.A.S.; Lima, E.O.; Agra, M.F.; Souza, M.F.V.K. Phytoconstituents from Sidastrum micranthum (A. St. Hil.) Fryxell (Malvaceae) and antimicrobial activity of pheophytin a. Braz. J. Pharm. Sci. 2015, 51, 181187.

26. Zhao, J. Phytochemical and antibacterial studies on Arctium lappa, Tussilago farfara and Verbascum thapsus. PhD Dissertation, University of Strathcylde Glasgow, Scotland, 2014, pp 142-156.

27. Shastri, M.D.; Shukla, S.D.; Chong, W.C.; Dua, K.; Peterson, G.M.; Patel, R.P.; Hansbro, P.M.; Eri, R. and O'Toole, R.F. Role of oxidative stress in the pathology and management of human tuberculosis. Oxid. Med. Cell. Longev. 2018, 1-10

28. Hsu, C.; Chao, P.; Hu, S.; Yang, C. The antioxidant activity and free radical scavenging activities of chlorophylls and pheophytins. Food Nutr. Sci. 2013, 4, 1-8. 